\title{
Nitrogen Fertilization Increases Windstorm Damage in an Aggrading Forest
}

\author{
Christopher A. Walter ${ }^{1, *}$, Zachariah K. Fowler ${ }^{1}$, Mary Beth Adams ${ }^{2}$, Mark B. Burnham ${ }^{3}$, Brenden E. McNeil ${ }^{4}$ \\ and William T. Peterjohn ${ }^{1}$ \\ 1 Department of Biology, West Virginia University, Morgantown, WV 26505, USA; \\ zfowler@mail.wvu.edu (Z.K.F.); william.peterjohn@mail.wvu.edu (W.T.P.) \\ 2 Northern Research Station, USDA Forest Service (Emeritus), Morgantown, WV 26505, USA; \\ Marybeth.adams@mail.wvu.edu \\ 3 Center for Advanced Bioenergy and Bioproducts Innovation, University of Illinois, Urbana, IL 61801, USA; \\ mburnham@illinois.edu \\ 4 Department of Geology and Geography, West Virginia University, Morgantown, WV 26506, USA; \\ brenden.mcneil@mail.wvu.edu \\ * Correspondence: cwalte12@mail.wvu.edu; Tel.: +1-304-293-5201
}

Citation: Walter, C.A.; Fowler, Z.K.; Adams, M.B.; Burnham, M.B.;

McNeil, B.E.; Peterjohn, W.T.

Nitrogen Fertilization Increases Windstorm Damage in an Aggrading Forest. Forests 2021, 12, 443. https://doi.org/10.3390/f12040443

Academic Editor: Leonor

Calvo Galvan

Received: 19 March 2021

Accepted: 3 April 2021

Published: 6 April 2021

Publisher's Note: MDPI stays neutral with regard to jurisdictional claims in published maps and institutional affiliations.

\begin{abstract}
Storms are the most significant disturbance events in temperate forests. Forests impacted by nitrogen deposition may face more severe storm damage as changes in soil and wood chemistry impact tree growth allocation, wood strength, and species composition. To examine these potential effects of nitrogen deposition, we measured tree damage from a windstorm in an aggrading forest that is part of a nitrogen fertilization experiment. We discovered that within the nitrogen fertilization treatment area there was significantly more basal area and stems damaged when compared to the reference treatment, and the nitrogen fertilization treatment had more snapped and severely damaged trees. Additionally, the effect of treatment and amount of damage to trees was different depending on tree species. If our results are indicative of the large and globally-distributed regions of temperate forests impacted by nitrogen deposition, then the increased windstorm disturbance risk posed by climate change could be more significant due to the effects of nitrogen deposition.
\end{abstract}

Keywords: disturbance; storm; damage; $\mathrm{N}$ deposition; temperate forest; acidification; acid rain; $\mathrm{N}$ saturation; windthrow

\section{Introduction}

Storms are the most significant source of disturbance in temperate forests [1]. Storm disturbance causes ecological disruption through the creation of canopy openings that alter tree mortality and recruitment [2,3]. Additionally, the litter from storm disturbance can accelerate nutrient cycling [4] and cause forests to become major sources of atmospheric carbon [5]. Such ecological effects from storm disturbances can alter forest ecosystems for centuries [6], and even millennia [7]. At shorter time scales, storm disturbance also causes economic disruption. Costs to forest managers include reduced timber value from either a real or perceived decrease in wood quality, restoration of access to forest sites, reduced market value due to sudden supply increase in the storm-affected area, and either long-term storage to wait for the market to rebound or long-distance transport of timber from outside of the storm-affected area [8]. At longer time scales, storm disturbances may weaken trees and make them more susceptible to secondary disturbances (e.g., insects, disease, drought, fire, additional storms) $[9,10]$, further increasing the ecological disturbance and lowering economic value.

The risk of forest storm disturbance has risen significantly with climate change [11,12]. Warming oceans have increased the frequency of large-magnitude storms $[13,14]$. Additionally, post-landfall storm power has increased, and it is more likely that storms will track 
further inland [15]. The economic effects of these extreme events can be staggering [16]. Hurricane Michael, which hit the Gulf Coast of the United States in October 2018, is an example of the threat storm disturbance poses to the timber industry. The hurricane damaged 1,133,120 ha of forest in the state of Florida, costing the timber industry $\$ 1.3$ billion dollars-more than $5 \%$ of the state's annual timber industry value [17]. The neighboring states of Georgia and Alabama were also impacted by Hurricane Michael. Georgia had 121,406 ha of forest damaged, costing $\$ 763$ million in timber revenue, and Alabama had 17,159 ha damaged, costing $\$ 32.7$ million dollars to the timber industry [17]. The major destructive force in these severe storms is wind, and its impact on forests may depend on the presence of additional disturbance factors [18].

Adding to the increased wind disturbance risk posed by the growing frequency of severe storms, other global change factors may interact with storms to create even greater levels of disturbance [19-21]. Nitrogen (N) deposition is one such global change factor that causes physiological changes in trees that may leave them more susceptible to storm damage. $\mathrm{N}$ deposition has been shown to reduce belowground biomass allocation in forests [22,23], leaving trees with disproportionately more stems and leaves relative to roots. Trees fertilized with $\mathrm{N}$ also grow faster, creating more reaction wood (called compression wood in gymnosperms and tension wood in angiosperms) [24,25]. Reaction wood grows in reaction to tensile stress and has a greater concentration of cellulose than lignin [25-27]. It is structurally weaker and more brittle than regular grain wood, making it more susceptible to failure under force [28]. $\mathrm{N}$ deposition may also change the species composition of forests and select for trees that are more or less susceptible to storm damage [5,29]. Finally, N deposition could also lead to more susceptible trees by enhancing herbivory $[30,31]$ and increasing pathogenic infection risk [32].

Evidence that $\mathrm{N}$ deposition may contribute to greater storm damage in forests is sparse. In a scrub mangrove forest, $\mathrm{N}$ fertilization led to a greater loss in leaf area index and slower recovery after two hurricanes damaged the forest in the same month [33]. The authors of the study suggested $\mathrm{N}$ fertilization led to increased aboveground biomass, which may have left mangrove trees more susceptible to intense wind [33]. In a tropical forest dominated by Metrosideros polymorpha, $\mathrm{N}$ and phosphorus $(\mathrm{P})$ fertilization ( $\mathrm{P}$ was more limiting to growth than was $\mathrm{N}$ at this site) caused greater damage from a hurricane [34]. However, the fertilized plots recovered from storm damage faster [34].

Perhaps the only evidence of an interaction between $\mathrm{N}$ deposition and storm damage in temperate forests is from Walter et al. 2019 [29]. In this study, the authors found damage from a severe snow storm (with relatively low wind speed) was lower in an $\mathrm{N}$ fertilized watershed and as $\mathrm{N}$ increased across a native $\mathrm{N}$ availability gradient [29]. Contrary to the increased damage expected from the horizontal forces of windstorms, the authors found that the more vertical vegetation structure linked to $\mathrm{N}$ enrichment provided an improved ability to shed heavy snowfall. Nevertheless, damage from snowstorms is not as common as from windstorms, and to our knowledge, no study within temperate deciduous forests has examined how $\mathrm{N}$ enrichment affects storm disturbance from wind.

Considering the lack of available studies documenting the interactive effects of $\mathrm{N}$ and storms in temperate forests, our objective was to examine whether enhanced $\mathrm{N}$ deposition led to greater windstorm damage in an aggrading temperate forest. To meet our objective, we surveyed trees in a long-term $\mathrm{N}$ fertilization experiment that experienced a severe windstorm. We hypothesized that the physiological and community composition effects of $\mathrm{N}$ fertilization would leave stands more susceptible to windstorm damage, causing damage to be greatest in areas undergoing $\mathrm{N}$ fertilization treatments.

\section{Materials and Methods}

\subsection{Study Site}

We assessed wind damage in the Long-Term Soil Productivity Experiment (LTSP) [35] at Fernow Experimental Forest (herein Fernow) in West Virginia, USA $\left(39.0563^{\circ} \mathrm{N}, 79.6979^{\circ} \mathrm{W}\right)$. Fernow is a 1902 ha research forest that primarily contains Appalachian mixed mesophytic 
forest and receives $1430 \mathrm{~mm} \mathrm{yr}^{-1}$ of precipitation on average. The LTSP experiment within Fernow was designed to test the effects of chronic $\mathrm{N}$ deposition in temperate forests. It consists of four treatments:

1. Whole-tree harvest (reference)

2. Whole-tree harvest + nitrogen $(+\mathrm{N})$

3. Whole-tree harvest + nitrogen + lime $(+\mathrm{N}+\mathrm{L})$

4. An unharvested treatment (unused in this study)

All aboveground biomass was removed from the whole-tree harvested treatments in the winter of 1996-1997. The $+\mathrm{N}$ and $+\mathrm{N}+\mathrm{L}$ treatments have been fertilized with ammonium sulfate at a rate of $35 \mathrm{~kg} \mathrm{~N} \mathrm{ha}^{-1} \mathrm{yr}^{-1}$ since 1997. The $+\mathrm{N}+\mathrm{L}$ treatments have been additionally fertilized with dolomitic lime at a rate of $22.5 \mathrm{~kg}$ calcium ha ${ }^{-1} \mathrm{yr}^{-1}$ since 1997. Each treatment is replicated four times and one replicate of each treatment was randomly assigned to a cell in each row of a 16-plot matrix at the beginning of the experiment. Each plot is 0.37 ha-containing a 0.2 ha quadrilateral area in the center where measurements are made, and a $7.6 \mathrm{~m}$ treated buffer that surrounds the treatment area on all sides. In addition to $\mathrm{N}$ fertilization, the LTSP also received an estimated $5.2 \mathrm{~kg} \mathrm{~N}^{-1}$ in 2011 from wet deposition of nitrate and ammonium (see Figure S1 for a time series of atmospheric wet deposition of $\mathrm{N}$ ).

The inclusion of both $+\mathrm{N}$ and $+\mathrm{N}+\mathrm{L}$ treatments in the LTSP experiment allows investigators to partition the dual ecosystem effects of $\mathrm{N}$ deposition: acidification and fertilization. The $+\mathrm{N}$ treatment both fertilizes and acidifies the soil, while the additional application of lime in the $+\mathrm{N}+\mathrm{L}$ treatment attempts to reduce the acidification effect by adding base cations to soil. Therefore, ecosystem effects appearing in $+\mathrm{N}$ treatments and not $+\mathrm{N}+\mathrm{L}$ treatments are more likely an effect of acidification. Effects appearing in both $+\mathrm{N}$ and $+\mathrm{N}+\mathrm{L}$ treatments are attributed more to the fertilization effect of $\mathrm{N}$.

In late December 2009, the LTSP experiment was damaged by a severe windstorm. There was very limited damage elsewhere in Fernow and extreme winds were not detected at nearby weather stations. Nevertheless, weather stations did indicate that thunderstorms crossed the region during late December, suggesting that the wind damage was from a severe downdraft or "microburst" that caused severe localized damage to just the mountainside containing the LTSP experiment. While we were unable to collect an instrumental estimate of wind speed, the damage to trees was extensive and the location of the LTSP experiment provided a globally rare opportunity to measure forest stand damage across a long-term $\mathrm{N}$ fertilization experiment.

Prior to the storm, the reference, $+\mathrm{N}$, and $+\mathrm{N}+\mathrm{L}$ treatments all had closed forest canopies. Fortunately, Fowler et al. 2014 completed a survey estimating forest composition in these treatments in summer 2009, several months prior to the storm [36]. Their survey determined that Prunus pensylvanica, Liriodendron tulipifera, Betula lenta, and Prunus serotina comprised $89 \%$ of the total basal area and $79 \%$ of the total stems when averaged across all treatments (see Table S1 in Supplementary Material for complete species composition). The pre-storm mean tree basal area across treatments was $19.7 \mathrm{~m}^{3} \mathrm{ha}^{-1}$ and the mean number of stems across treatments was $5691 \mathrm{ha}^{-1}$. Since species differ in physiology and response to $\mathrm{N}$ and lime fertilization, we formed species-specific hypotheses that were informed by published growth and allocation responses to N and lime (Table S2 in Supplementary Material for the initial species-specific damage hypotheses).

\subsection{Damage Measurement}

We measured damage from the December 2009 windstorm in summer 2011 in reference, $+\mathrm{N}$, and $+\mathrm{N}+\mathrm{L}$ treatment areas of the LTSP experiment. Based on regular visual assessments in the time between the storm and our survey, we did not note any other intervening disturbances that would have confounded ascribing damage to the 2009 event. To maximize our sampling effort, we took advantage of the composition survey by Fowler et al. 2014 [36] that had been completed just before the storm. Fowler et al. 2014 [36] had measured the basal area and identified all trees to species in six randomly selected sub- 
plots within each treatment plot. We returned to the same subplots in 2011 and identified each tree to species, measured the basal area, and visually categorized the damage of all damaged trees within the subplots. We categorized the damage of each tree in two stages: damage type and damage severity. Damage type consisted of the following categories:

- Bent-a tree that was bent by wind or a collision with another tree

- Tipup - a tree that had been uprooted and was leaning

- Snap-a tree that was snapped either at the main stem or at a major branch

Damage severity consisted of the following categories, based on angle relative to a vertical tree:

- Moderate- 0 to 22.5 degrees from vertical

- Significant-23 to 45 degrees from vertical

- Extensive-45.5 to 67.5 degrees from vertical

- Prostrate-greater than 67.5 degrees from vertical

Damage severity could be assigned to any damage type, making all combinations of damage type and severity possible.

The 2009 composition survey provided the total number of stems and basal area, by species, in each of the six subplots within each treatment plot in the LTSP experiment. The 2011 damage measurement provided the same data, except it only included damaged trees, and also included the damage type and severity of each damaged tree. We combined of the 2009 composition survey dataset and the 2011 damage measurement dataset to calculate the response variables used in statistical analysis.

\subsection{Statistical Analysis}

To examine differences in damage across the LTSP experimental treatments, we used four main response variables: percentage of basal area damaged, percentage of stems damaged, damage type, and damage severity. To calculate both the percentage of basal area damaged and the percentage of stems damaged, we treated damage as a binary variable. Trees were either damaged (regardless of their damage type or severity) or undamaged. In each subplot, we divided the sum of basal area damaged (2011 data) by the total basal area (2009 data) and multiplied by 100 to calculate the percentage of basal area damaged. Similarly, in each subplot, we divided the number of damaged trees (2011 data) by the total number of trees (2009 data) and multiplied by 100 to calculate the percentage of stems damaged. To determine whether the percentage basal area or stems damaged differed by species, we calculated both variables in each subplot for P. pensylvanica, L. tulipifera, B. lenta, and P. serotina.

We calculated the damage type and severity as the percentage of total damaged stems in each category. In each subplot, we divided the number of trees in a damage category by the total number of damaged trees in the subplot and multiplied by 100 . We used each category label as an individual response, which resulted in three response variables for damage type (bent, tipup, and snap) and four response variables for damage severity (moderate, significant, extensive, and prostrate). Using both of these categorical variables allowed us to determine whether treatments led to differences in either damage type or severity among the percentage of stems damaged.

To test whether the experimental treatments led to differences in the damage in any of the response variables examined, we used bootstrap hypothesis tests, following an approach from Walter et al. 2017 [37]. The following scheme outlines the process:

1. Sample 24 subplots in each treatment, with replacement

2. Calculate the mean of each response variable from the sample

- Mean percentage of basal area damaged (five means: all species, P. pensylvanica, L. tulipifera, B. lenta, and P. serotina)

- Mean percentage of stems damaged (five means: all species, P. pensylvanica, L. tulipifera, B. lenta, and P. serotina) 
- Mean percentage of stems damaged by damage type (three means: bent, tipup, and snap)

- Mean percentage of stems damaged by damage severity (four means: moderate, significant, extensive, and prostrate)

3. Repeat 50,000 times

4. Calculate $\mathrm{p}$-value as the fraction of times the bootstrap mean was different from the empirical mean of the comparison treatment

The $p$-value, testing whether the bootstrap mean of a treatment was greater than the empirical mean of a comparison treatment, was calculated as:

$$
\frac{\sum_{i=1}^{n}\left[\bar{y}_{\text {boot }_{i}}<\hat{\mu}\right]}{n}
$$

where $n$ indicates the number of bootstrap sample iterations $(50,000)$ and brackets indicate a Boolean true/false return of the inequality asking whether the bootstrap sample mean $\left(\bar{y}_{\text {boot }}\right)$ of a treatment was less than the empirical mean of a comparison treatment $(\hat{\mu})$. Summation across all iterations (i) from 1 to $n$ is simply the count of the number of times the inequality was true. In the cases where we tested whether the bootstrap sample mean of treatments was less than the empirical mean of a comparison treatment, the $p$-value was calculated as:

$$
\frac{\sum_{i=1}^{n}\left[\bar{y}_{\text {boot }_{i}}>\hat{\mu}\right]}{n}
$$

Testing differences in 17 response variables across three treatments resulted in 51 hypothesis tests. To estimate family-wise error in multiple comparisons, we calculated the false discovery rate among statistically significant $(p<0.05)$ test results using the Benjamini-Hochberg procedure [38]. This procedure estimates the fraction of false positive tests expected and has three major advantages over other methods (e.g., Bonferroni procedures): (i) its results are independent of test quantity, (ii) there are no additional arbitrary significance thresholds to select, and (iii) calculating and reporting false positive rate does not increase Type-II error probability. Out of 51 tests, we found 21 to be significant at $p<0.05$, with a false positive rate of 11.7 percent (See Table S3 in Supplementary Material for a complete list of $p$-values and false positive rates). At this rate, we can expect about two or three (2.46) of the 21 positive tests to be false positives.

The LTSP experiment uses a randomized block design to examine the effect of controlled additions of fertilizer, but the blocking factor (slope position) [31] was not chosen to account for an unanticipated disturbance event. As a result, we used a bootstrap approach to maximize the statistical power of our datasets in a way that should improve our ability to assess the impact of a chance event on an established, long-term experiment. More specifically, bootstrap hypothesis testing, applied across sublots within the LTSP plots, allowed us to amplify the signal of damage differences among experimental treatments. We performed all analyses in R Statistical Software Version 4.0.2 for Mac [39], and all data and the $\mathrm{R}$ code used to perform the analysis are available on GitHub at https://github.com/waltscience/forest-wind-damage and archived on Zenodo [40].

\section{Results}

\subsection{Basal Area and Stems Damaged}

The 2009 windstorm damaged $29.7 \%$ of basal area, when averaged across all treatments and tree species. Across all species, the percentage of basal area damaged was greater in both the $+\mathrm{N}+\mathrm{L}$ (33.4\% damage; $p=0.022)$ and $+\mathrm{N}(33.2 \%$ damage; $p=0.045)$ treatments areas when compared to that of the reference treatment area (22.7\% damage; Figure 1a). Treatments also affected the percentage of basal area damaged in individual species. The percentage of $P$. serotina basal area damaged was greater in both the $+\mathrm{N}+\mathrm{L}(17.3 \%$ damage; $p<0.001)$ and $+\mathrm{N}(10.5 \%$ damage; $p=0.031)$ treatment areas, relative to that of the reference treatment area $(1.2 \%$ damage; Figure 1a). L. tulipifera was damaged more in the $+\mathrm{N}$ 
treatment area $(27.7 \%$ damage $)$ than it was in the $+\mathrm{N}+\mathrm{L}$ treatment area $(10.9 \%$ damage; $p=0.016)$, while no significant difference was detected between either treatment and the reference treatment (17.6\% damage).
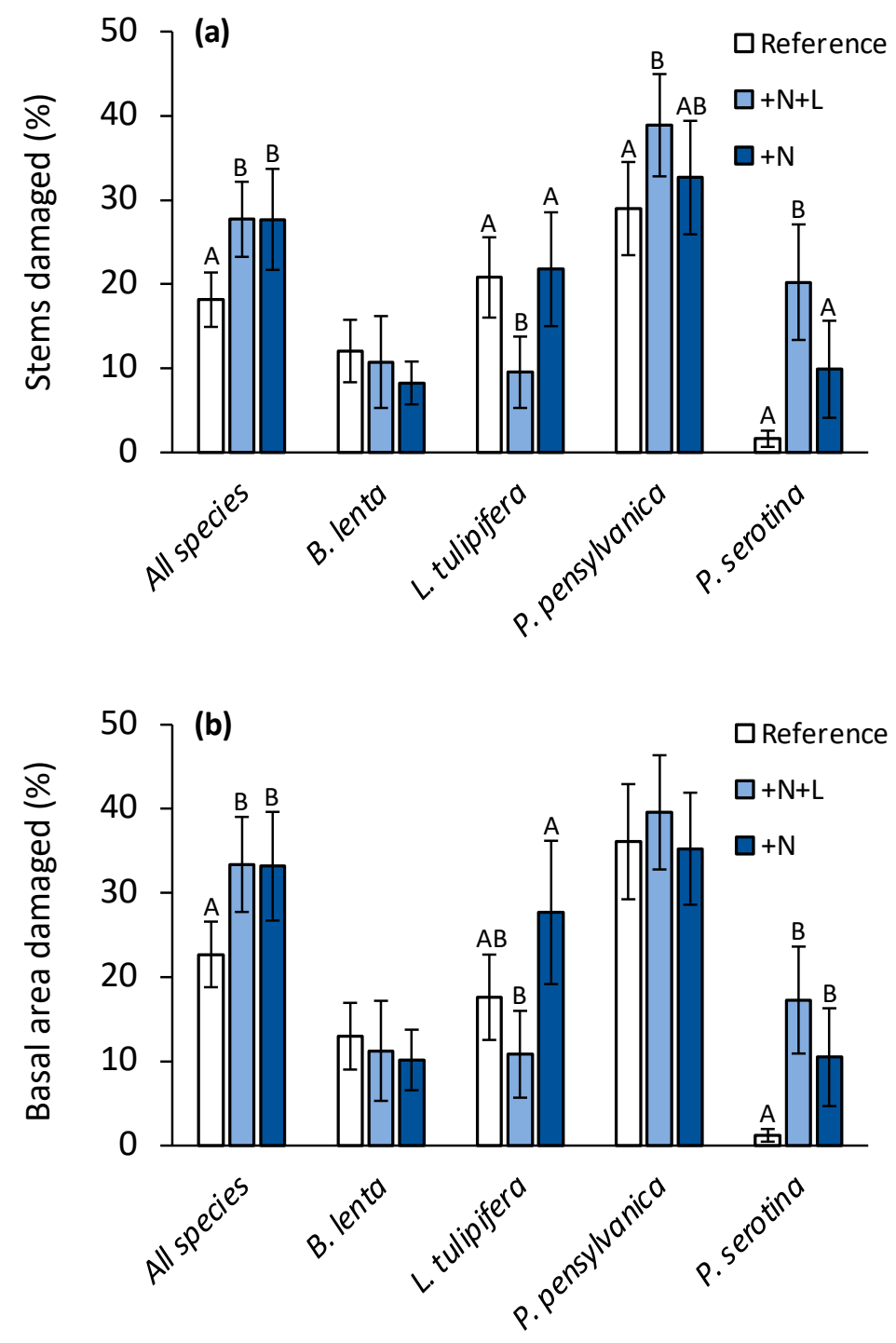

Figure 1. Tree damage from a windstorm across the reference, nitrogen fertilized $(+\mathrm{N})$, and nitrogen and lime fertilized $(+\mathrm{N}+\mathrm{L})$ treatment areas in the Long-Term Soil Productivity Experiment (LTSP) Experiment: (a) Percentage of total basal area damaged across all tree species and within the four dominant tree species; (b) Percentage of total stems damaged across all tree species and within the four dominant tree species. Bars and error bars represent the empirical means and one standard error, respectively. Differences in capital letters within a species group denote significant differences $(p<0.05)$ between treatments, determined by bootstrap hypothesis tests.

The windstorm damaged $24.5 \%$ of individual tree stems, when averaged across all treatments and tree species. Across species, the percentage of stems damaged by the storm was greater in both $+\mathrm{N}+\mathrm{L}(27.7 \%$ damage; $p=0.012)$ and $+\mathrm{N}$ treatment areas $(27.7 \%$ damage; $p=0.047)$, when compared to that of the reference treatment area (18.2\% damage; Figure $1 \mathrm{~b})$. Treatments also affected the percentage of stems damaged among individual tree species. The percentage of $P$. pensylvanica stems damaged was greater in the $+\mathrm{N}+\mathrm{L}$ treatment area $(73.1 \%$ damage) than it was in the reference treatment area (46.5\% damage; $p=0.045)$, but the percentage of damaged stems in the $+\mathrm{N}$ treatment area $(62.5 \%$ damage $)$ was not statistically different from that in the $+\mathrm{N}+\mathrm{L}$ treatment area or the reference treatment 
area. Similarly, the magnitude of damage among P. serotina stems was higher in the $+\mathrm{N}+\mathrm{L}$ (9.5\% damage) treatment area than it was in the $+\mathrm{N}(4.3 \%$ damage; $p=0.047)$ or reference treatment areas $(8.1 \%$ damage; $p<0.001)$. Conversely, L. tulipifera stems were damaged less frequently in the $+\mathrm{N}+\mathrm{L}$ treatment area (9.5\% damage) than they were in either the $+\mathrm{N}$ (21.8\% damage; $p=0.025$ ) or reference treatment areas ( $20.8 \%$ damage; $p=0.008)$.

\subsection{Damage Type and Severity}

The majority of stem damage from the windstorm was from bent trees $(55.9 \%)$, followed by tipup trees $(14.9 \%)$, and snapped trees $(10.9 \%)$, when averaged across all treatments. Comparing treatments, the percentage of snapped trees was greater in the $+\mathrm{N}$ treatment area $(16.7 \% ; p=0.010)$ compared to that of the reference treatment area $(6.1 \%)$. The percentage of snapped trees was also greater in the $+\mathrm{N}+\mathrm{L}$ treatment area $(10.2 \%$; $p=0.021$ ) than it was in the reference treatment area (Figure 2a).
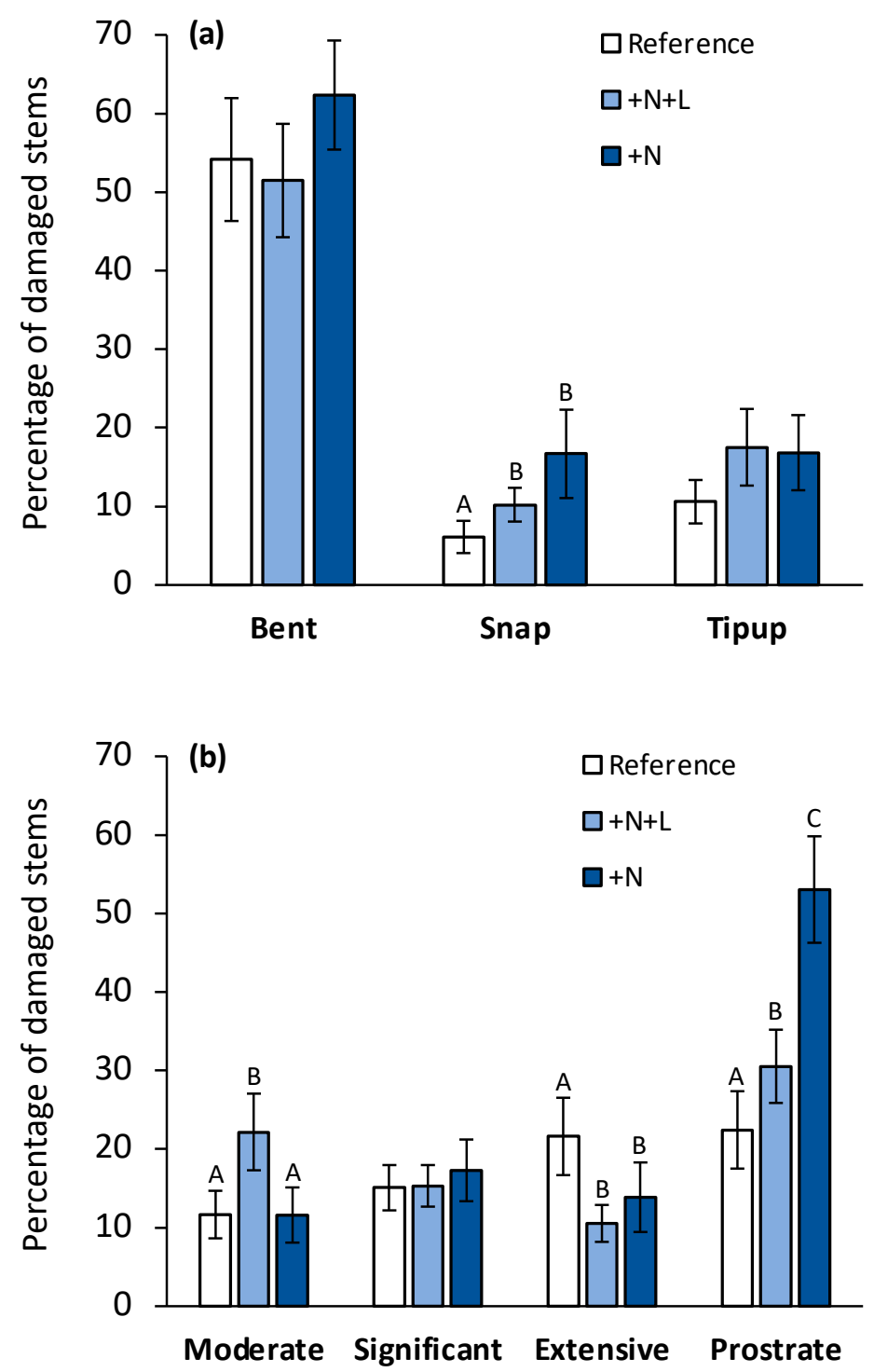

Figure 2. Stem damage from a windstorm across the reference, nitrogen fertilized $(+\mathrm{N})$, and nitrogen and lime fertilized $(+\mathrm{N}+\mathrm{L})$ treatments in the LTSP Experiment: (a) Percentage of tree stems damaged by damage type; (b) Percentage of tree stems damaged by damage severity. Bars and error bars represent the empirical means and one standard error, respectively. Differences in capital letters within either a type or severity group denote significant differences $(p<0.05)$ between treatments, determined by bootstrap hypothesis tests. 
When averaged across all treatments, the windstorm resulted in a greater frequency of severely damaged (prostrate) stems (35.3\%) than the frequency of stems found in less severe damage categories: significant damage (15.9\%), extensive damage (15.3\%), and moderate damage $(15.1 \%)$. Comparing treatments, there was a greater percentage of trees that experienced moderate damage in the $+\mathrm{N}+\mathrm{L}$ treatment area $(22.2 \%)$ when compared to that of either $+\mathrm{N}(11.6 \% ; p=0.004)$ or reference $(11.7 \% ; p=0.007)$ treatment areas (Figure $2 b)$. For trees that experienced extensive damage, there was a greater percentage found in the reference treatment area $(21.6 \%)$ compared to that from either the $+\mathrm{N}+\mathrm{L}(10.5 \% ; p<0.001)$ or $+\mathrm{N}(13.9 \% ; p=0.048)$ treatment areas. The percentage of damaged stems found in the prostrate category differed across all three treatment areas, with the $+\mathrm{N}$ treatment area having a greater frequency of prostrate trees (53\%) than that of both the $+\mathrm{N}+\mathrm{L}$ treatment area $(30.5 \% ; p<0.001)$ and reference treatment area $(22.4 \% ; p<0.001)$. The percentage of prostrate trees in $+\mathrm{N}+\mathrm{L}$ treatment area was also greater than the percentage in the reference treatment area $(p=0.038)$.

\section{Discussion}

After 12 years of ammonium sulfate additions, we found that the extent of damage from a localized windstorm was enhanced by fertilizer additions. While numerous studies have reported forest disturbance levels from storms [41], few studies measured storm impacts in stands with experimental $\mathrm{N}$ treatments [29], and none, that we are aware of, attempted to partition the dual ecosystem effects of $\mathrm{N}$ deposition between fertilization $(+\mathrm{N}+\mathrm{L})$ and the combination of both fertilization and acidification $(+N)$. Here, the fertilization-only treatment $(+\mathrm{N}+\mathrm{L})$ led to significantly more windstorm damage. However, we also found the combination of fertilization and acidification $(+\mathrm{N})$ had a strikingly similar effect on stand damage, suggesting that greater stand damage resulted more from the fertilization effect of $\mathrm{N}$, rather than acidification.

Across all tree species, both $\mathrm{N}$ fertilization and $\mathrm{N}$ and lime fertilization led to a $10.6 \%$ increase in basal area damage and a $9.5 \%$ increase in the number of stems damaged. $\mathrm{N}$ fertilization can increase both basal area (diameter growth) and decrease stem density (thinning) [42]. Taken together, the strong effect observed in both basal area and stem damage is evidence that $\mathrm{N}$ fertilization made stands more susceptible to a windstorm, irrespective of any secondary $\mathrm{N}$ effects on diameter growth or thinning. We suspect that $\mathrm{N}$ additions made the stands in our study more susceptible by changing patterns of biomass allocation and/or reductions in wood strength.

Multiple forest fertilization studies have found that trees tend to allocate more biomass aboveground with $\mathrm{N}$ fertilization [22,23,37]. This is consistent with evidence from a separate experiment at Fernow, where $\mathrm{N}$ fertilization has made trees $2.5 \mathrm{~m}$ taller, on average [29], and caused a $25 \%$ increase in aboveground net primary productivity with no detectable change in belowground productivity [43]. Thus, we suspect $\mathrm{N}$ fertilization led to a similar change between above and belowground allocation in the LTSP plots, possibly making trees more susceptible to wind damage because they become more "top heavy" from biomass being disproportionately allocated aboveground. Furthermore, tree height has widely been reported as being positively correlated with storm damage [44-46].

Beyond the potential effects of shifts in biomass allocation, $\mathrm{N}$-fertilized trees may also be more susceptible to damage by producing weaker wood. Indeed, faster growing trees may have decreased wood strength due to the production of more tension wood [47]. Tension wood is created on the upper side of a tree stem under tension, and is characterized by an abundance of cellulose [27]. Tension wood is generally weaker than wood growing under normal tensile conditions [28] and $\mathrm{N}$ fertilization has been shown to increase production of tension wood in Populus $[25,26]$. Thus, while an increase in aboveground allocation in $\mathrm{N}$ fertilized treatments may help explain the overall increase in damage in $\mathrm{N}$ fertilized treatments (Figure 1), an increase in tension wood formation in $\mathrm{N}$ fertilized treatments could have led to the greater percentage of snapped and prostrate trees in the $+\mathrm{N}$ treatment (Figure 2). 
When we examined the effects for different species, we found differences in damage between treatments for P. serotina, P. pensylvanica, and L. tulipifera, but the patterns varied depending on how storm damage was assessed: percent basal area or percentage of stems damaged. P. serotina has been observed to be particularly susceptible to wind damage because it has a relatively shallow rooting depth and grows taller than its neighbor trees [48]. The greatest percentage of $P$. serotina stems was damaged in the $+\mathrm{N}+\mathrm{L}$ treatment area, with the addition of base cations. This was surprising, considering $P$. serotina growth is diminished on sites with greater soil base cation concentrations [49], and experimental lime fertilization slows P. serotina growth and increases mortality [50]. In the case of P. serotina, increased aboveground allocation may not explain the observed increase in the percentage of stems damaged. Instead, it is plausible that the addition of calcium (Ca) led to decreased wood strength in the $+\mathrm{N}+\mathrm{L}$ treatment. Calcium nutrition has been shown to impact wood quality in other hardwood species [51], as such, it may be possible that lime fertilization reduced wood quality in P. serotina. Similar to P. serotina, there was a greater percentage of $P$. pensylvanica stems damaged in the $+\mathrm{N}+\mathrm{L}$ treatment area, when compared to those damaged the reference area. We hypothesize these results may be because P. pensylvanica is a congener of $P$. serotina, although less is known about how base cations affect $P$. pensylvanica growth and mortality because of its short lifespan and noncommercial status.

In contrast to the Prunus results, a smaller percentage of L. tulipifera stems were damaged in $+\mathrm{N}+\mathrm{L}$ treatment area when compared to those damaged in both the reference and $+\mathrm{N}$ treatment areas. Additionally, a smaller percentage of L. tulipifera basal area was damaged in the $+\mathrm{N}+\mathrm{L}$ treatment area when compared to that in the $+\mathrm{N}$ treatment area (Figure 1). This was surprising because $\mathrm{N}$ fertilization in a nearby experiment at Fernow led to diminished growth in L. tulipifera [52]. Because of this, we expected lower L. tulipifera damage in both $+\mathrm{N}$ and $+\mathrm{N}+\mathrm{L}$ treatment areas based on our hypothesis that increased aboveground allocation would increase wind damage. However, the main difference in $L$. tulipifera damage was between $+\mathrm{N}$ and $+\mathrm{N}+\mathrm{L}$ treatments, which suggests the addition of lime had an effect in addition to altering biomass allocation. The addition of $\mathrm{N}$ fertilizer decreases L. tulipifera wood density [53], potentially by reducing the availability of $\mathrm{Ca}$ and magnesium ( $\mathrm{Mg}$ ) in soil [52]. If the process by which $\mathrm{N}$ fertilization reduced wood density was through diminished availability of soil $\mathrm{Ca}$ and $\mathrm{Mg}$, the addition of $\mathrm{Ca}$ (such as in the $+\mathrm{N}+\mathrm{L}$ treatment) could potentially increase wood density under $\mathrm{N}$ fertilization. The increased wood density may lead to greater wood strength and reduced damage from wind, as observed in the $+\mathrm{N}+\mathrm{L}$ treatment area.

The species-specific responses in this study add evidence that allocation is not solely responsible for the observed differences in wind damage due to $\mathrm{N}$ fertilization. P. serotina was a tree we expected would shift allocation aboveground in response to $\mathrm{N}$ addition and acidification ( $+\mathrm{N}$ treatment) because of its documented preference for soils with lower $\mathrm{Ca}$ and Ma concentrations. In response to greater aboveground allocation, we hypothesized $P$. serotina trees growing in the $+\mathrm{N}$ treatment would be more susceptible to wind damage. Instead, the number of damaged P. serotina stems was greatest with the addition of both $\mathrm{N}$ and lime $(+\mathrm{N}+\mathrm{L}$ treatment). In a contrasting example, we expected $L$. tulipifera would allocate less aboveground with $\mathrm{N}$ addition and acidification ( $+\mathrm{N}$ treatment), considering its observed decline in growth in response to $\mathrm{N}$ addition. In this instance, we hypothesized L. tulipifera trees growing in the $+\mathrm{N}$ treatment would be damaged less by the windstorm. However, we discovered a greater percent basal area and percentage stem damage in the $+\mathrm{N}$ treatment area, and less damage in the $+\mathrm{N}+\mathrm{L}$ treatment. These results suggest that growth and allocation alone likely cannot fully explain the differences in damage we observed among species. Instead, there are likely many physiological factors (including wood strength) affected by $\mathrm{N}$ fertilization that determine the extent of forest damage due to wind.

While our experiment lacked the power to fully disentangle the intricate species composition and physiological interaction effects brought on by $\mathrm{N}$ fertilization, those interactions will likely remain quite difficult to elucidate experimentally [54]. The relatively 
scant number of long-term forest fertilization experiments, combined with the variable nature of severe storms, makes studying the interaction of the two a rarity. However, greater insight may be gained by studying storm disturbance across historic $\mathrm{N}$ deposition gradients (such as in the eastern United States) with available regional to continental-scale data products and monitoring programs, including the U. S. Forest Service's Forest Inventory and Analysis program (FIA), the Smithsonian Institution's Forest Global Earth Observatory (ForestGEO), and the Battelle Memorial Institute's National Ecological Observation Network (NEON).

Our study showed that $\mathrm{N}$ fertilization significantly increased tree damage from a windstorm in an aggrading temperate forest, and damage differed among tree species and $\mathrm{N}$ fertilization treatments. As global climate change increases the frequency and landfall power of large-magnitude storms, forests are already at an increased risk of disturbance. Based on our findings, temperate forests receiving current or historically high $\mathrm{N}$ deposition may be at an even greater risk of storm damage from wind.

Supplementary Materials: The following are available online at https://www.mdpi.com/article/ 10.3390/f12040443/s1, Figure S1: Total inorganic nitrogen wet deposition at Fernow, Table S1: Tree species composition by percentage of stems and percentage of basal area across three treatments in the LTSP experiment, Table S2: Species-specific hypotheses for storm damage based on published traits and responses to nitrogen and lime in fertilization and gradient studies, Table S3: Results for 51 bootstrap hypothesis tests across species group, damage type, and damage severity as either percentage of stems or basal area of trees damaged from the 2009 windstorm.

Author Contributions: Each author made significant and unique contributions to this paper: Conceptualization, C.A.W., M.B.A., Z.K.F., M.B.B., B.E.M., and W.T.P.; formal analysis, C.A.W.; investigation, C.A.W., M.B.A., Z.K.F., M.B.B., B.E.M., and W.T.P.; data curation, C.A.W.; writing-original draft preparation, C.A.W.; writing-review and editing, C.A.W., M.B.A., Z.K.F., M.B.B., B.E.M., and W.T.P.; supervision, M.B.A., B.E.M., and W.T.P.; funding acquisition, M.B.A., B.E.M., and W.T.P. All authors have read and agreed to the published version of the manuscript.

Funding: This research was funded by The National Science Foundation's Long-Term Research in Ecosystem Biology program, grant numbers DEB-0417678 and DEB-1019522, the U. S. Department of Agriculture Forest Service Northern Research Station, and the West Virginia University Eberly College of Arts and Sciences.

Institutional Review Board Statement: Not applicable.

Informed Consent Statement: Not applicable.

Data Availability Statement: The data and R code used to perform the analysis in this study are available on GitHub at https:/ / github.com/waltscience/forest-wind-damage and archived on Zenodo at https:// doi.org/10.5281/zenodo.4487873.

Acknowledgments: We thank Doug Owens and Chris Cassidy for building and maintaining the LTSP experiment, Dara Erazo Lilian Hill, Ty Heimerl, Justin Lego, and Devon Raiff for their help with field work and data entry, two anonymous reviewers for their feedback on our manuscript, and the United States Forest Service for their foresight and support of long-term forest ecology research.

Conflicts of Interest: The authors declare no conflict of interest and the funders had no role in the design of the study; in the collection, analyses, or interpretation of data; in the writing of the manuscript, or in the decision to publish the results.

\section{References}

1. Fischer, A.; Marshall, P.; Camp, A. Disturbances in deciduous temperate forest ecosystems of the northern hemisphere: Their effects on both recent and future forest development. Biodivers. Conserv. 2013, 22, 1863-1893. [CrossRef]

2. Batista, W.B.; Platt, W.J. Tree population responses to hurricane disturbance: Syndromes in a south-eastern USA old-growth forest. J. Ecol. 2003, 91, 197-212. [CrossRef]

3. Canham, C.D.; Papaik, M.J.; Latty, E.F. Interspecific variation in susceptibility to windthrow as a function of tree size and storm severity for northern temperate tree species. Can. J. For. Res. 2001, 31, 1-10. [CrossRef]

4. Houlton, B.Z.; Driscoll, C.T.; Fahey, T.J.; Likens, G.E.; Groffman, P.M.; Bernhardt, E.S.; Buso, D.C. Nitrogen Dynamics in Ice Storm-Damaged Forest Ecosystems: Implications for Nitrogen Limitation Theory. Ecosystems 2003, 6, 431-443. [CrossRef] 
5. $\quad$ Busing, R.T.; White, R.D.; Harmon, M.E.; White, P.S. Hurricane disturbance in a temperate deciduous forest: Patch dynamics, tree mortality, and coarse woody detritus. Plant Ecol. 2008, 201, 351-363. [CrossRef]

6. Foster, D.R.; Knight, D.H.; Franklin, J.F. Landscape Patterns and Legacies Resulting from Large, Infrequent Forest Disturbances. Ecosystems 1998, 1, 497-510. [CrossRef]

7. Mitchell, S.J. Wind as a natural disturbance agent in forests: A synthesis. Forestry 2012, 86, 147-157. [CrossRef]

8. Hanewinkel, M.; Peyron, J.L. The Economic Impact of Storms; The European Forest Institute: Joensuu, Finland, 2013.

9. Paine, R.T.; Tegner, M.J.; Johnson, E.A. Compounded Perturbations Yield Ecological Surprises. Ecosystems 1998, 1, 535-545. [CrossRef]

10. Bigler, C.; Kulakowski, D.; Veblen, T.T. Multiple disturbance interactions and drought influence fire severity in rocky mountain subalpine forests. Ecology 2005, 86, 3018-3029. [CrossRef]

11. Reyer, C.P.O.; Bathgate, S.; Blennow, K.; Borges, J.; Bugmann, H.; Delzon, S.; Faias, S.P.; Garcia-Gonzalo, J.; Gardiner, B.; Gonzalez-Olabarria, J.R.; et al. Are forest disturbances amplifying or canceling out climate change-induced productivity changes in European forests? Environ. Res. Lett. 2017, 12, 034027. [CrossRef]

12. Seidl, R.; Thom, D.; Kautz, M.; Martin-Benito, D.; Peltoniemi, M.; Vacchiano, G.; Wild, J.; Ascoli, D.; Petr, M.; Honkaniemi, M.P.J.; et al. Forest disturbances under climate change. Nat. Clim. Chang. 2017, 7, 395-402. [CrossRef]

13. Zhao, M.; Held, I.M. An Analysis of the Effect of Global Warming on the Intensity of Atlantic Hurricanes Using a GCM with Statistical Refinement. J. Clim. 2010, 23, 6382-6393. [CrossRef]

14. Emanuel, K. Increasing destructiveness of tropical cyclones over the past 30 years. Nat. Cell Biol. 2005, 436, 686-688. [CrossRef]

15. Li, L.; Chakraborty, P. Slower decay of landfalling hurricanes in a warming world. Nat. Cell Biol. 2020, 587, 230-234. [CrossRef]

16. Smith, A.B. 2010-2019: A Landmark Decade of U.S. Billion Dollar Weather and Climate Disasters; National Oceanic and Atmospheric Administratio: Washington, DC, USA, 2020. Available online: https://www.climate.gov/news-features/blogs/beyond-data/20 10-2019-landmark-decade-us-billion-dollar-weather-and-climate (accessed on 1 April 2021).

17. Brody, A.R. Weathering the Storm: Assessing the Agricultural Impact of Hurricane Michael; The Southern Office of The Council of State Governments: Atlanta, GA, USA, 2019.

18. Rogers, P. Disturbance Ecology and Forest Management: A Review of the Literature; USDA Forest Service Intermountain Research Station: Odgen, UT, USA, 1996.

19. Bradford, J.B.; Fraver, S.; Milo, A.M.; D'Amato, A.W.; Palik, B.; Shinneman, D.J. Effects of multiple interacting disturbances and salvage logging on forest carbon stocks. For. Ecol. Manag. 2012, 267, 209-214. [CrossRef]

20. Hermosilla, T.; Wulder, M.A.; White, J.C.; Coops, N.C. Prevalence of multiple forest disturbances and impact on vegetation regrowth from interannual Landsat time series (1985-2015). Remote Sens. Environ. 2019, 233, 111403. [CrossRef]

21. Cobb, R.C.; Metz, M.R. Tree Diseases as a Cause and Consequence of Interacting Forest Disturbances. Forestry $2017,8,147$. [CrossRef]

22. Stober, C.; George, E.; Persson, H. Carbon and Nitrogen Cycling in European Forest Ecosystem; Shulze, E.D., Ed.; Springer-Verlag: Berlin, Germany, 2000; pp. 99-121.

23. Li, W.; Jin, C.; Guan, D.; Wang, Q.; Wang, A.; Yuan, F.; Wu, J. The effects of simulated nitrogen deposition on plant root traits: A meta-analysis. Soil Biol. Biochem. 2015, 82, 112-118. [CrossRef]

24. Sastry, C.B.R. Some Effects of Fertilizer Application on Wood Properties of Douglas Fir (Pseudotsuga menziesii). Master's Thesis, University of British Columbia, Vancouver, BC, Canada, 1967.

25. Pitre, F.E.; Pollet, B.; Lafarguette, F.; Cooke, J.E.K.; Mackay, J.J.; Lapierre, C. Effects of Increased Nitrogen Supply on the Lignification of Poplar Wood. J. Agric. Food Chem. 2007, 55, 10306-10314. [CrossRef] [PubMed]

26. Pitre, F.E.; Lafarguette, F.; Boyle, B.; Pavy, N.; Caron, S.; Dallaire, N.; Poulin, P.-L.; Ouellet, M.; Morency, M.-J.; Wiebe, N.; et al. High nitrogen fertilization and stem leaning have overlapping effects on wood formation in poplar but invoke largely distinct molecular pathways. Tree Physiol. 2010, 30, 1273-1289. [CrossRef]

27. Bentum, A.L.K.; Cote, W.A.; Day, A.C.; Timell, T.E. Distribution of lignin in normal and tension wood. Wood Sci. Technol. 1969, 3, 218-231. [CrossRef]

28. Wimmer, R.; Johansson, M. The Biology of Reaction Wood; Gardiner, B., Barnett, J., Saranp ää, P., Gril, J., Eds.; Springer-Verlag: Berlin, Germany, 2014; pp. 225-248.

29. Walter, C.A.; Burnham, M.B.; Adams, M.B.; McNeil, B.E.; Deel, L.N.; Peterjohn, W.T. Nitrogen Availability Decreases the Severity of Snow Storm Damage in a Temperate Forest. For. Sci. 2020, 66, 58-65. [CrossRef]

30. Massad, T.J.; Dyer, L.A. A meta-analysis of the effects of global environmental change on plant-herbivore interactions. Arthropod Plant Interact. 2010, 4, 181-188. [CrossRef]

31. Li, F.; Dudley, T.L.; Chen, B.; Chang, X.; Liang, L.; Peng, S. Responses of tree and insect herbivores to elevated nitrogen inputs: A meta-analysis. Acta Oecol. Int. J. Ecol. 2016, 77, 160-167. [CrossRef]

32. Hesterberg, G.A.; Jurgensen, M.F. The relation of forest fertilization to disease incidence. For. Chron. 1972, 48, 92-96. [CrossRef]

33. Feller, I.C.; Dangremond, E.M.; Devlin, D.J.; Lovelock, C.E.; Proffitt, C.E.; Rodriguez, W. Nutrient enrichment intensifies hurricane impact in scrub mangrove ecosystems in the Indian River Lagoon, Florida, USA. Ecology 2015, 96, 2960-2972. [CrossRef] [PubMed]

34. Herbert, D.A.; Fownes, J.H.; Vitousek, P.M. Hurricane Damage to a Hawaiian Forest: Nutrient Supply Rate Affects Resistance and Resilience. Ecology 1999, 80, 908-920. [CrossRef] 
35. Adams, M.B.; Burger, J.; Zelazny, L.; Baumgras, J. Description of the Fork Mountain Long-Term Soil Productivity Study: Site Characterization; USDA Forest Service Northern Research Station: Newtown Square, PA, USA, 2004.

36. Fowler, Z.K. The Effects of Accelerated Soil Acidification on Aggrading Temperate Deciduous Forests: The Fernow Experimental Forest Long Term Soil Productivity (LTSP) Study at 13 Years. Ph.D. Thesis, West Virginia University, Morgantown, WV, USA, 2014.

37. Walter, C.A.; Adams, M.B.; Gilliam, F.S.; Peterjohn, W.T. Non-random species loss in a forest herbaceous layer following nitrogen addition. Ecology 2017, 98, 2322-2332. [CrossRef]

38. Benjamini, Y.; Hochberg, Y. Controlling the False Discovery Rate-A Practical and Powerful Approach to Multiple Testing. J. R. Stat. Soc. Ser. B Methodol. 1995, 57, 289-300. [CrossRef]

39. R-Core-Team. R: A Language and Environment for Statistical Computing; R Foundation for Statistical Computing: Vienna, Austria, 2020.

40. Walter, C.A.; Fowler, Z.K.; Adams, M.B.; Burnham, M.B.; McNeil, B.E.; Peterjohn, W.T. Tree damage from a 2009 windstorm in a temperate forest nitrogen fertilization experiment. Zenodo 2021. [CrossRef]

41. Everham, E.M.; Brokaw, N.V.L. Forest damage and recovery from catastrophic wind. Bot. Rev. 1996, 62, 113-185. [CrossRef]

42. Harper, J.J. Population Biology of Plants; Academic Press: Cambridge, MA, USA, 1977; p. 892.

43. Eastman, B.A.; Adams, M.B.; Brzostek, E.R.; Burnham, M.B.; Carrara, J.E.; Kelly, C.; McNeil, B.E.; Walter, C.A.; Peterjohn, W.T. Altered plant carbon partitioning enhanced forest ecosystem carbon storage after 25 years of nitrogen additions. New Phytol. 2021. [CrossRef]

44. Lohmander, P.; Helles, F. Windthrow probability as a function of stand characteristics and shelter. Scand. J. For. Res. 1987, 2, 227-238. [CrossRef]

45. Griess, V.C.; Knoke, T. Growth performance, windthrow, and insects: Meta-analyses of parameters influencing performance of mixed-species stands in boreal and northern temperate biomes. Can. J. For. Res. 2011, 41, 1141-1159. [CrossRef]

46. Lanquaye-Opoku, N.; Mitchell, S.J. Portability of stand-level empirical windthrow risk models. For. Ecol. Manag. 2005, 216, 134-148. [CrossRef]

47. Savidge, R.A. Wood Quality and Its Biological Basis; Barnett, J.R., Jeronimisi, G., Eds.; Blackwell Scientific: Oxford, UK, 2003.

48. Marquis, D.A. Silvics of North America. Volume 2. Harwoods; Burns, R.M., Honkala, B.H., Eds.; U.S. Department of Agriculture, Forest Service: Washington, DC, USA, 1990; pp. 594-604.

49. Long, R.P.; Horsley, S.B.; Hallett, R.A.; Bailey, S.W. Sugar maple growth in relation to nutrition and stress in the northeastern United States. Ecol. Appl. 2009, 19, 1454-1466. [CrossRef]

50. Long, R.P.; Horsley, S.B.; Hall, T.J. Long-term impact of liming on growth and vigor of northern hardwoods. Can. J. For. Res. 2011, 41, 1295-1307. [CrossRef]

51. Lautner, S.; Ehlting, B.; Windeisen, E.; Rennenberg, H.; Matyssek, R. Calcium nutrition has a significant influence on wood formation in poplar. New Phytol. 2007, 173, 743-752. [CrossRef]

52. Jensen, N.K.; Holzmueller, E.J.; Edwards, P.J.; Gundy, M.T.-V.; Dewalle, D.R.; Williard, K.W.J. Tree Response to Experimental Watershed Acidification. Water Air Soil Pollut. 2014, 225. [CrossRef]

53. Ross, D.; Buckner, E.; Core, H.; Woods, F. Nitrogen Fertilization Decreases Yellow-Poplar Wood Density. South. J. Appl. For. 1979, 3, 119-122. [CrossRef]

54. Xi, W.; Peet, R.K. Recent Hurricane Research-Climate, Dynamics, and Societal Impacts; Lupo, A., Ed.; Intech Publishers: London, UK, 2011; pp. 503-534. 